\title{
МАТЕРИЈАЛНОСТ ПЕСМЕ ПОПА Д. ЂУРЂЕВА (ИНТЕРМЕДИЈАЛНОСТ ПОЕЗИЈЕ КОЈА СЕ ГЛЕДА $)^{2}$
}

Песничка збирка Поезија која се гледа Попа Д. Ђурђева (2018) представља надмоћ визуелног над вербалним, а другачија форма упутила је песника ка формирању нових обликотворних поступака, форми представљања и формирању новог знака. Поп Д. Ђурђев дисконтинуиране визуелне знакове распоређује у циклусе „Песме без речи“ и „Песмине слике речи“, користећи разнолик материјал визуелне поезије (слова, бројеви, научни симболи, исечци из штампе, рекламни материјал, фотографије, разни уметнички и неуметнички цртежи).

Кључне речи: визуелна песма, цртеж, поезија, криптограм, знак

Поезију Попа Д. Ђурђева препознајемо управо по интермедијалности, односно по иконичко-текстуалним колажима који демонстрирају гледање као читање и читање као својеврсну игру и палимпсест значења. Критика пише о „процесу разградње постојећег како би се изградила нова естетичка форма“ (ОПАЧИЋ 2019: 6), односно о духу „деструктивног неимарства“"3, чиме се читање претвара у заводљиву игру решавања ребуса, односно дешифровања (ЈОЦИЋ 2013: 4). Материјали које користи Ђурђев у поезији су и уметничког и неуметничког порекла - уметничке илустрације, дизајнерска решења симбола и разноразни материјал подређен је новој уметничкој целини, чија се значења усмеравају вербалним интервенцијама, а то су када је реч о књизи Поезија која се гледа углавном наслови песама. Текст се обликује као колаж од илустрација, фотографија, иконичких представа, брендова робних марки и слова која уобличавају или довршавају језичке изразе, а на тај на-

\footnotetext{
${ }^{1}$ milenakulic1@gmail.com

${ }^{2}$ Рад је изложен на округлом столу „Интертекстуалност и интемедијалност у књижевном делу Попа Д. Ђурђева“, одржаном у Нишу 22. марта 2019. године.
}

${ }^{3}$ Аутопоетичко одређење (Ђурђев 1998). 
чин поезија Попа Д. Ђурђева постаје „отворено дело које дозвољава и омогућава различите доживљаје промишљања и тумачења" (СТОЛИЋ 2019: 74). На први поглед, ова књига изгледа као визуелна поезија без конвенционалних стихова, сачињена од песама-колажа, песама-ребуса и песама-стрипова (в. ЉУШТАНОВИЋ 2013: 143), погодна за млађе читаоце, с обзиром на то да се „чита, гледа, слуша, одгонета“ (ЛОМОВИЋ 2013: 147). Визуелна поезија, која развија „пострадовићевско наслеђе“ (ОПАЧИЋ 2019: 7), свакако може бити подстицајна за анализу у светлу сигналистичких визуелних песама, које се могу сагледати у овом поетичком контексту. Сигналистички визуелна песма има свој натпис или наслов, који у појединим случајевима може да се односи на текстуалну песму, причу или поглавље романа које прати. Јелена Марићевић Балаћ уочава извесне разлике између емблематичности визуелне поезије Попа Д. Ђурђева и сигналистичких визуалија, истичући да би била грешка да ову поезију посматрамо искључиво као сигналистичку, с обзиром на то да Ђурђев даје нови смисао слици и речима, чинећи значајан отклон у односу на сигналистичко поетичко стваралаштво:

Кључна разлика тицала би се карактера „потписа““, будући да је сигналистички „потпис“ нечитљив и рециклиран, а може се објаснити потрошношћу новинских вести које не садрже трајну вредност и представљају шум у комуникацији. Ђурђевљеви су, пак, усмерени на индивидуални печат сваког реципијента понаособ или их он сам завршава стиховима у појединим песмама из књиге Радови на млечном путу, какве су, примера ради, „Абориџински ауфингер“ или „Пусти пужу рогове“. Док сигналистички потпис упућује на ограничавање рецепцијских могућности, Ђурђев подстиче неограниченост и креативност стварања или класичну интерпретацију понуђених стихова (МАРИЋЕВИЋ БАЛАЋ 2019: 51).

Даница Столић мишљења је да Ђурђевљеву поезију не би требало тумачити као искучиво сигналистичку, с обзиром да песник даје „нови смисао слици и речима, тако што морфолошки план често остаје исти, али са уочавањем и истицањем комбинованих садржаја унутар постојећих, уз њихово визуелно наглашавање“ (СТОЛИЋ 2019: 61). ${ }^{4}$ У том смислу, Предраг Јашовић додатно наглашава отклон Попа Д. Ђурђева у односу на сигнализам - „Мирољуб Тодоровић ствара песму да се гледа, а Ђурђев ствара песму да се чита и гледањем 'допише' и да се њена полисемичност тако 'продужи'“ (Јашовић 2014: 68) Особен „семантички кључ“ (ПАВЛОВИЋ 2002: 314) који је Поп Д. Ђурђев развио у оквиру

\footnotetext{
${ }^{4}$ „Сигнализам Попа Д. Ђурђева је особен, могли бисмо га дефинисати као неосигнализам, с обзиром да и Ђурђев користи разнородне сигнале у поезији за децу и младе, али на сасвим нови начин, с обзиром на друго време и околности у којима ствара и с обзиром на другачији уметнички сензибилитет“ (СТОЛИЋ 2019: 69).
} 
различитих комбиновних форми захтева „креативно читање“ (ЈОЦИЋ 2013: 5), односно еманципованог читаоца, рансијеровски речено, који је спреман да одгонетне синкретичне песме које се гледају. Однос текстуалног и визуелног „осцилује од уобичајених текстуалних песама до песама без текста“" (ОПАЧИЋ 2019: 10).

Овде сведочимо заиста иновацији у визуелизацији лирског израза, као и такозваном „попђурђевском палимпсесту који се описује као вишеслојни вид интертекстуалности где се у вештом комбиновању и рекомбиновању постојећих књижевних и и културолошких садржаја спајају иновативним поступцима традиција и савременост, а где је језички кључ суштинска спона са семантичко-асоцијативним решењима“ (СТОЛИЋ 2019: 34). Поп Д. Ђурђев „дисконтинуиране визуелне знакове“ распоређује у циклусе „Песме без речи“ и „Песмина слика речи“, користећи разнолик материјал визуелне поезије, тј. такозвану „ребус поезију“ (ЈОЦИЋ 2013: 3). П Поезији која се гледа неопходно је прићи имајући у виду да у нашој књижевности елементе визуелне поезије имамо још у средњовековној књижевности, развијену визуелну поезију гаји барок у својим криптограмима и облицима carmina figurata, у романтизму код Ђорђа Марковића Кодера, у авангарди код дадаиста и зенитиста (Алексића, Пољанског, Мицића и других) и код надреалиста, а и знатно касније, код песника који не припадају овој песничкој оријентацији (као што је Љубомир Симовић у песми „Рortus regius“, у којој се тражи таутолошка веза визуелног и значењског). Од појаве првих књига за децу присутна је наклоност визуелним елементима, а „склоност медијском синкретизму (...) једна је од битних особина књижевности за децу“ (љУШТАНОВИЋ

\footnotetext{
${ }^{5}$ „Збирка Поезија која се гледа подељена је на две целине, у којима се визуелизација третира на два начина, па бисмо рекли да су то два типа визуелизације. У том смислу, песник их је и класификовао у две целине. Прва је насловљена 'Песме без речи', а друга 'Песмине слике речи'. Суштинска разлика између ове две песничке целине огледа се у чињеници да је прва искључиво састављена од графичких представа, на свакој страници је по једна слика, настала комбиновањем ликовних садржаја. Друга целина као визуелне елементе користи клип-арт графику, корпоративни лого, творећи један посебан вид графовизуелне песме. (...) У првом делу збирке најпре уочавамо и издвајамо фразеолошко груписање уклопљено са сликовним изразом. Песник користи познате фразе као наслове својих визуелних песама за њихове ликовне представе, за оригиналну комбинаторику и сликовно-језичку конкретизацију. Нема сумње да су оне тим поступком иновиране, изнова актуелизоване и 'освежене': Прсти у око, затим крилатица: Свако време носи своје бреме, стара порука, 'наравоученије', окрњено за други свој део: Пиши као шито говориш, али већ на следећој страници духовито решење у новој фрази: Пиши као шишо метьеи, дечја брзалица која може бити у служби бројалице (разбрајалице): Пустии ӣужу рог̈ове, Колико музике тиолико и йара, Конаи, дело краси, Койийа не скийа, Где нема кукавица, има хероја. Друго груписање односило би се на друге, већ познате текстовне структуре: Теши, иееши йанана, Злочин и казна, Лимени добош. Том кругу припада и песма: Шексииирова мишоловка, Десаниина дрва, Росинијев Вильем Тел, Змајева Илијада (СТОЛИЋ 2019: 67-68).
} 
2004: 43). О улози игре у поезији Попа Д. Ђурђева пише Јован Љуштановић:

Поп Д. Ђурђев припада песничкој традицији која се увелико изборила за право поезије за децу на игру блиску дечјем мишљењу, језику и осећању света, на спонтану и слободну асоцијативност, еуфорију, досетку која изневерава очекивања и иде до нонсенса и коју, барем на први поглед, и не занимају „виши облици игре“, „игре друштвеног типа“, како их је замишљао и описао Хуизинга (љУШТАНОВИЋ 2019: 29).

Дадаистичка традиција у стварању лако се уочава када је упоредимо са неким српским издањима: часопис Дада Танк из 1922. године, карактеристичан је по сродном онеобичавању текста, односно по поигравању његовим визуелним могућностима. Читање постаје игра и одгонетање, а то је поетика од које Ђурђев очигледно полази и развија је. Ове песме се у потпуности дешифрују, сачињене су као колажи маркетиншких симбола уз минималне текстуалне интервенције и значењска преусмерења: „Време је за рекламе“, „Пионири малени“, „Веш плав и лав“. Таква врста окренутости медијским садржајима присутна је и у делима Љубивоја Ршумовића, Драгомира Ђорђевића, Дејана Алексића и других, по мишљењу Зоране Опачић, као „нека врста прећутно прихваћеног стилског означења које често представља симбол урбаног начина живота“ (ОПАЧИЋ 2019: 12).

Када је у питању књига Поезија која се гледа, посебно интересантне јесу управо илустрације које упућују на робне марке и рекламе. Таквом тумачењу би требало прићи имајући у виду да медијске праксе све више утичу на теме и обележја књижевности за децу, како тумачи Владислава Гордић Петковић у тексту „Медији и технологија у књижевности за децу и омладину“ (2014: 4-8). У том смислу парадигматична је ЕПП песма чији су стихови грађени од комбинације различитих робних марки и брендова, те се на тај начин приближава сигналистичкој визуалији, али се и разликује у погледу читљивости и употребе логотипа, који су у целости искоришћени и обликују текстовну раван песме. Оваква песма упућује на преиспитивање стварности и представља сигнум потрошачког друштва или окупираности брендовима, маркама и једнодимензионалним амблемима. На тај начин, показује се песничка

способност да различите елементе културе, кодификоване структуре и културне конструкте, подвргава дечјем начину мишљења и односу према свету, али и његова способност да прекорачује границе различитих културних подручја и равни и да успоставља неочекиване односе и везе упркос увреженим разграничењима (љУШТАНОВИЋ 2019: 39).

Овакву врсту поезије не можемо тумачити уколико не размотримо суштину рекламног материјала, који је коришћен у формирању стихов- 
них структура и поетике песничке игре. Динамичан дијалог између визуелног и текстовног у рекламним порукама гради полиграфију - комбинацију фотографије и типографије. Полиграфија захтева револуционарно опредељење за мултимедијалност и иновативност. У том контексту парадигматичан је текст под насловом „Модерна реклама“, који уз помоћ Јо Клекове „Рекламе“ текстом и сликом, конструише рекламну стратегију часописа „Зенит“ 1924. године. У есеју су, зенитистички смело, идентификоване две кључне фазе у модерној рекламној пракси: најпре је потребно робу именовати - што се саопштава помоћу текста, а потом је потребно робу показати - што се врши помоћу фото-механике. Суштина свих рекламних конструкција или кампања током читавог века рекламе може се препознати у поштовању ове једноставне процедуре коју су изнели сарадници Зенита 1924. године. Дакле, именовати, а онда показати робу, и то баш у мултимедијалној форми, непогрешива је рекламна стратегија која директно води до глобалног брендирања. „Треба знати да је модеран човек преплављен натписима и плакатима. Зато је најцелисходније робу показати уместо да се само именује. Потребно је фотографско показивање предмета или његово дејство или обоје заједно да се испуни површину плаката или огласа. За ову сврху мора се претпоставити фотомеханичка репродукција свакој мање или више спретно цртаној или сликаној репродукцији“ препоручио је аутор „Модерне рекламе“, потписан иницијалима ДВС у авангардном ,Зениту“.

У природи је фотографског кадра или слике у било ком виду да региструје фрагментарно и деконструисано тело, а не тоталну реалност. Зато је и у Поезији која се гледа присутно радикално исецање, уоквиравање, кадрирање, носилац агресивних импулса објективизације у визуелним представама. Познато је да оквир слике фрагментарно исеца свет тако да тај фрагмент онда фунционише као синегдоха. Наиме, израз сугерише да то што је понуђено погледу чини само део живота, али и да се све оно што је остало ван оквира или кадра не разликује од понуђене слике. Дакле, када је издвојио мањи део света, али по принципу синегдохе, тај део, фрагмент стоји уместо целине. По истом принципу, уживалац рекламе треба само да попуни рекламну слику властитим животним искуством, емоцијама и знањима. Он стално додаје оно што треба да стоји у заградама рекламне визуелне реторике, исто као што читалац Поезије која се гледа треба да ово отворено дело испуни својим читалачким искуствима. Интертекстуалност је у књизи Поезија која се гледа несумњиво представила слику света и на неки начин представља „хипертрофиран књижевни поступак“, слично улози коју интертекстуалност има у књизи Етичко чишћење, о чему пише Јован Љуштановић: 
У овој поезији песнички субјекат сладострасно скаче о цитата до цитата, од парафразе до парафразе, од асоцијације до асоцијације. У њој се непрестано ресемантизују и деконструишу постојећи и конструишу неки нови мисаони и културни контексти. Асоцијативни распони су невероватни. Ђурђев укршта високо и ниско: библијске и античке асоцијације, народне умотворине и стихове српских књижевних класика, с чињеницама из новинских вести и популарне културе. Само се у овој поезији могу сусрести она секира која је одсекла главу Карађорђу у Радовањском лугу и народна изрека „секира му упала у мед“ (љУШТАНОВИЋ 2019б: 75).

Проучавање штампаних рекламних порука, насловних страна и плаката из прве половине 20. века може бити више него драгоцено, како у читању актуелних постера и билборда, тако у разумевању дугорочних и мултинационалних рекламних стратегија на телевизији или на интернету. Реклама је модерна религија глобалног потрошачког друштва. У тој планетарној заједници, одавно, више није важно оно „бити“ него оно „имати“, како је нагласио Ги Дебор у својој анализи Друштво спектакла (ДЕБОР 2003: 34). Мултимедијалне и мултипликоване рекламне поруке заједно са глобалним тржиштем граде јединствен систем значења, престижа и идентитета тако што асоцијативно везују само неке производе са пожељним животним стиловима, симболичним вредностима и задовоствима. Јер сваки посматрач-потрошач мора знати да огласи не носе само информацију, већ и друштвено посредована симболична значења. Ниједан читалац-гледалац неке рекламе, али исто тако ниједан читалац поезије која се гледа, не може се тек тако ослободити присног и моћног загрљаја слике илузије, фантазмагоричне, ониричке и халуцинантне представе коју негде у себи препознаје као властиту слику или представу о идеалном ја.

Потенцирајући интензивну свест реципијената, Поп Д. Ђурђев је, према мишљењу Данице Столић, „померио границе поезије за децу и младе, користећи фоничне игре, језик реклама и логоа које су у суштини спољашње манифестације савременог потрошачког друштва“:

Ова монтажна поезија, поезија колажа, криптограма, графике, оригинално и ефектно је „дизајнирана“ тако што је песник створио особен хибрид. Различити логотипови су сједињени у смислене целине које се могу гледати и читати, тачније добијају потпуно нову функционалност. Песник им одузима рекламну улогу и даје им сасвим нову и значајнију улогу песничку. Примећујемо да се песме римују, најчешће по моделу укрштене риме, а да су „строфе“ катрени (ЕППесма, Артикулащија логотипа) (СТОЛИЋ 2019: 72).

Та нова публика успоставила је и нова правила игре у свакодневном животу. Тачније, знатно веће масе учесника произвеле су промену у начи- 
ну учествовања, приметио је Валтер Бенјамин, имајући у виду стару јадиковку да „масе једино траже забаву“, што се показало неизоставним у медијском простору. Појава цртежа, односно визуелних представа у илустрованим огласима, већ у првој деценији 20. века требало је да подстакне задовољство гледања слика. У поређењу са оном старом, текстуалном и сажетом формом оглашавања која је била наметнута, у значајној мери и комерцијалним разлозима, слика, најпре цртеж, а онда и фотографија, умела је много више да каже малом човеку. Другим речима, индустријска роба захтевала је „индустрију слика“. Масовну визуелизацију робе, гарантовала је механичка слика - фотографија. Реторика слика је, у светлу брендова и реклама, не само убедљивија него и заводљивија од текста.

Поп Ђурђев, имајући све ово у виду, врло успешно је реализовао „логичко-лудистичку замисао испевавања Кола Бранка Радичевића на алхамијаду“ (в. СТОЛИЋ 2019: 72). Песма „Бранково коло на алхамијаду“, спајањем поетичких несагласности „осмишљава коло неких нових људи, без романтичарских емоција и патетике, где се братско коло гради и игра виловито по другом типу сличности, афинитета и намера“. „То коло је коло потрошачких конзумената“, како тврди Даница Столић (2019: 73). У песми „Време је за рекламе“ песник поручује да за Пинокијево стварање није неопходан стрпљиви столар Ђепето, нити његова вештина и духовна вредност. Комбиновањем различитих визуелних знакова, добро укомбинованих, добијемо текст песме: „Провери да ли / за Пинокија / даска фали / па ако ти фали / онда батали / Без доброг / сувог облутка / нема ни повести / једног лутка“ (ЂУРЂЕВ 2018). Визуелну перцепцију поезије песник је наставио и у књизи Етичко чишћење: бревијар јутутунских похвала лудости у песмама „Плава птица“, „Витрувијево распеће“, „Корешподенција“", „Магритова фру/лула“, „У потрази за каноном“, „Дан и ноћ“, „Композиција без композиције“, „Сенке прошлости“, „Краљевство без коња“, „Аријаднино купко“ (ЂУРЂЕВ 2019).

У овом каталогу новоговора савременог света односно у економско-пропагадном циклусу песник заиста показује да је време за рекламе, те користи различите брендове, попут телефонских, козметичких, аутомобилских и пољопривредних индустријских компанија. Да је то одиста тако песник и желео, показује и насловна страница циклуса „Песмине слике речи“" где можемо читати поетолошки исказ:

Ово је Базарски речник, каталог регистрованих слика речи новоговора савременог света илити есперанта потрошачког друштва. Комуникација логотипом (економско-пропагандни арго) је повратак идеограмском писму. Поетика визуелизованих језичких сурогата неодољиво подсећа на египатске сликовне епитафе. Убија ли нас то прејако дизајнирана реч или су Базари будућност света који настаје? (ЂУРЂЕВ 2018) 
Та миљковићевски названа „прејако дизајнирана реч“ умногоме је заменила ону песничку, којом се баве деценије песника и књижевних критичара. „Време које настаје“ бавиће се овом дизајнираном, материјалном речју, као нечим што нам је преостало или нешто што смо сачинили за наше сутра. Оваквим темама се у историји књижевности различито приступало, у зависности од епохе у којој један стваралац уметнички обликује своје дело. Несумњиво, такав визуелни и значењски идентитет поезије Попа Д. Ђурђева умногоме доприноси књижевности за децу уопште. Песме Попа Д. Ђурђева најчешће имају дупло дно, закључио је Јован Љуштановић. Свако читање, тумачење, надограђивање и гледање такве поезије биће само покушај да се допре до тог значења, до те мисли, до те идеје, до тог осећања које иде у бескрај. Да ли ћемо сви успети у томе - не знам.

\section{Цитирана литература}

Дебор, Ги, Друштво спектакла, Београд 2003.

Ђурђев 1998: Ђурђев, Поп Д. Слик ковнища: албум апокрифне хрестоматије, Дневник, Нови Сад 1998.

Ђурђев 2018: Ђурђев, Поп Д. Поезија која се гледа, Media Art Content, Нови Сад 2018.

Ђурђев 2019: Ђурђев, Поп Д. Етичко чишћење. Бревијар јутутунских похвала лудости, Media Art Content, Нови Сад 2019.

Јашовић 2014: Јашовић, Предраг, „Визуелизација као интертекстуална и жанровска прожимања у поезији Попа Д. Ђурђева“, Детињство, бр. 1, Нови Сад 2014.

Јоцић 2013: Јоцић, Милош, „Ребус поезија Попа Д. Ђурђева“, Детиюство, год. 39, бр. 3, Нови Сад 2013.

Ломовић 2013: Ломовић, Бошко, „Без узора и следбеника“, Луча, год. 22, бр. 2/3, 2013.

Љуштановић 2004: Љуштановић, Јован, Црвенкапа гриика вука (студије и есеји о књижевности за деиу), Дневник - Змајеве дечје игре, Нови Сад 2004.

Љуштановић 2013: Љуштановић, Јован, „Култура као велика играоница (Поп Д. Ђурђев: Радови на млечном путу, Васпитно запуштене песме, Чекић, Београд, 2012), Поља, год. 58, бр. 483, Нови Сад 2013.

Љуштановић 2019а: Љуштановић, Јован, „О подетињењу homo ludensa у поезији за децу Попа Д. Ђурђева“, у: Песничке игре и поиграваға Попа Д. Ђурђева, Зборник радова са научног скупа одржаног на 30. Међународном фестивалу хумора за децу у Лазаревцу, 19. септембра 2018. године, Библиотека Димитрије Туцовић, Међународни фестивал хумора за децу, Лазаревац 2019. 
Љуштановић 2019б: Љуштановић, Јован, „Без очију изван сваког зла“, Етичко чишћење: Бревијар јутутунских похвала лудости, Media Art Content, Нови Сад 2019.

Марићевић Балаћ 2019: Марићевић Балаћ, Јелена, „Тата-мата емблемата. Поезија попа Д. Ђурђева у светлу емблематике“, у: Песничке игре и поиграваға Попа Д. Бурђева, Зборник радова са научног скупа одржаног на 30. Међународном фестивалу хумора за децу у Лазаревцу, 19. септембра 2018. године, Библиотека Димитрије Туцовић, Међународни фестивал хумора за децу, Лазаревац 2019.

Опачић 2019: Опачић, Зорана, „Деструктивно неимарство Попа Д. Ђурђева $\&$ интертекстуално поигравање у поеми Мрюавчевићu“, у: Песничке игре и поигравања Попа Д. Ђурђева, Зборник радова са научног скупа одржаног на 30. Међународном фестивалу хумора за децу у Лазаревцу, 19. септембра 2018. године, Библиотека Димитрије Туцовић, Међународни фестивал хумора за децу, Лазаревац 2019.

Павловић 2002: Павловић, Миливоје, Визуелна поезија. Авангарда, неоавангарда и сигнализам, Просвета, Београд 2002.

Петковић Гордић, Владислава, „Медији и технологија у књижевности за децу и омладину: блог као ново тематско-структурно обележје литерарне и филмске форме, Детиғство, бр. 2, Нови Сад 2014.

Столић 2019: Столић, Даница, „Два типа визуелизације у збирци Поезија која се гледа Попа Д. Ђурђева“, у: Песничке игре и поигравања Попа Д. Ђурђева, Зборник радова са научног скупа одржаног на 30. Међународном фестивалу хумора за децу у Лазаревцу, 19. септембра 2018. године, Библиотека Димитрије Туцовић, Међународни фестивал хумора за децу, Лазаревац 2019.

\section{Milena Ž. Kulić}

\section{THE MATERIALITY OF THE SONGS BY POP D. ĐURĐEV}

Summary: The book of poetry Poezija koja se gleda by Pop D. Đurđev (2018) represents a superiority of visual over verbal while different forms direct the poet to new forms of representation. Pop D. Đurđev arranges discontinuous visual signals in cycles: Pesme bez reči, Pesmina slika reči using at the same time various materials of the visual poetry (letters, numbers, scientific symbols, press, promotional material, photographs, different art, and non-art drawings). Visual poetry is noticeable in our middle age literature, baroque (cryptograms and Carmina figurata), romanticism (Đorđe Marković Koder), avant-garde (dadaists and zenitists), surrealists and later on at some different poets such as Ljubomir Simović with his poem Portus regious. All this will be considered in our approach to the poetry of Pop D. Đurđev. 